\title{
Energy Sector Reforms and its Role of Economic Development with Special Reference to Tamilnadu
}

\author{
S. Thangamayan ${ }^{1 *}$, B. Chithirairajan ${ }^{2}$, S. Sudha ${ }^{3}$ \\ ${ }^{1}$ Assistant Professor, Department of Economics, VELS Institute of Science, Technology and Advanced Studies, Pallavaram, Chennai. \\ ${ }^{2}$ Assistant Professor, Department of Economics, VELS Institute of Science, Technology and Advanced Studies, Pallavaram, Chennai. \\ E-mail:chithirairajan89@gmail.com \\ ${ }^{3}$ Assistant Professor, Department of Economics, VELS Institute of Science, Technology and Advanced Studies, Pallavaram, Chennai. \\ E-mail:ssudha.ph.d@gmail.com \\ *Corresponding author E-mail:drthangamayaneco@gmail.com
}

\begin{abstract}
Energy is an important input for the sustained growth of an economy. Its use by individual households and the industrial units is on the increase. Energy can be an effective weapon in the battle against poverty in a country like India. Since the days of the second five ye ar plan of energy consideration of self-reliance as economic objectives induced the government to provide special emphasis to the development of heavy and basic industries like Iron, Steal, Heavy Machinery, Fertilizer, cement, Aluminum, Petrochemical etc. It costs about Rs. 4 crore to create new generation capacity. Non-conventional source of energy being the most environment friendly, there was an urgent need to promote generation of electricity based on such sources of energy; efforts have to been made to re duce the capital cost of projects based on non-conventional and renewable sources of energy.
\end{abstract}

Keywords: Consumption, economic development, energy, industries.

\section{Introduction}

Energy is an important input for the sustained growth of an economy. Its use by individual households and the industrial units is on the increase. It gets spread to all the sectors of the economy including agriculture and transport. Because of its cost efficiency it finds multiple uses even in the rural areas. The ease with which it is used increases the demand for it. Its consumption serves as an index of a country's economic development. In the modern world, energy plays a significant role in the economic development of a country. Electricity is the most versatile form of energy and provides an important infrastructure for economic development. Electric power has proved itself the legitimate aspiration of the people to have better social and economic living conditions. It is mobility by itself it can be brought to the people. The key to economic prosperity lies in judicious planning and effective management of energy resources. The per capita consumption of energy is an index of an economy's development. The gross national Product regression analysis indicates a strong positive relationship [1]. Today every Country draws its energy needs from a variety of Sources; we can broadly categorize these sources as.
1. Renewable and Non-Renewable sources
2. Conventional and Non-Conventional Sources
3. Direct and Indirect energy Sources.
4. Commercial and Non-Commercial Sources

In an industrialized country like USA, most of the energy requirements are met from commercial sources while in industrially less developed countries like India, they are using commercial and non-commercial energy sources.

\section{Energy and Economic Development}

Energy has been a vital element of economic growth and human progress has progressively been dependent on the use and adequacy of power. It is the most critical and important input for agricultural and industrial production. The development of agriculture and industry the expansion of infrastructural facilities and the transport sector have necessitated ever increasing investment in energy resources dependent as well as usable forms of energy in the house hold sector, the range of energy development on consumer durables has greatly expanded. As such the importance, of energy to the national economy is now more than its direct contribution to the gross national product (GNP) as it not only serves as a basic input but also acts as a catalyst for economic development and growth. Power is an important input for development and it is universally required in the Production of Commodities and services, it also provides basic amentias to the life of the entire population of a country. Energy can be an effective weapon in the battle against poverty in a country like India. Since the days of the second five year plan of energy consideration of self-reliance as economic objectives induced the government to provide special emphasis to the development of heavy and basic industries like Iron, Steal, Heavy Machinery, Fertilizer, cement, Aluminum, Petrochemical etc. Which are all energy intensive industries? The consumption 
goods Industries like textiles, sugar, paper which are quite energy intensive also received high priority.

\section{Methodology}

\section{Statement of the Problem}

Electricity is a concurrent subject of economic development, electricity is an important source of energy and it has become a part of human life, we cannot imagine day-today like and economic development without electricity. This study was chosen due to the special interest to know about the performance of TNEB, along with generation consumption, financial performance and sale of power of the board.

\section{Objectives of the Study}

1. To analyses the number of consumers and connected load of different category

2. To analyses the technical category financial performance of TNEB.

\section{Tools of Analysis}

The statistical tools are used to analyses the collected data and to interpret the research.

- Linear Growth Rate

- Semi_log model

Table 1: Electricity Sales by Agricultural Purposes in Tamil Nadu Over the Period

\begin{tabular}{|l|c|c|}
\hline Year & Agricultural Purpose & Percentage \\
\hline $2000-01$ & 4509.8 & 11.13 \\
\hline $2001-02$ & 5226.5 & 15.89 \\
\hline $2002-03$ & 5706.2 & 8.34 \\
\hline $2003-04$ & 6296.1 & 10.33 \\
\hline $2004-05$ & 6730.3 & 6.89 \\
\hline $2005-06$ & 6936.1 & 3.05 \\
\hline $2006-07$ & 7281.0 & 4.97 \\
\hline $2007-08$ & 7587.6 & 4.21 \\
\hline $2008-09$ & 8875.2 & 16.96 \\
\hline $2009-10$ & 9311.7 & 4.91 \\
\hline $2010-11$ & 9030.0 & -3.02 \\
\hline $2011-12$ & 9030.0 & 0 \\
\hline $2012-13$ & 9382.0 & 3.89 \\
\hline $2013-14$ & 9766.0 & 4.09 \\
\hline $2014-15$ & 9926.0 & 1.63 \\
\hline $2015-16$ & 10358.0 & 4.35 \\
\hline $2016-17$ & 10717.0 & 3.46 \\
\hline
\end{tabular}

Source: Tamil Nadu Electricity Board Statistics at a Glance.

Table 2: Electricity Sales by Commercial Purposes in tamil nadu

\begin{tabular}{|l|l|l|}
\hline Year & Commercial Purpose & Percentage \\
\hline $2000-01$ & 1172.4 & -1.46 \\
\hline $2001-02$ & 1135.4 & -3.16 \\
\hline $2002-03$ & 1176.4 & 3.61 \\
\hline $2003-04$ & 1602.0 & 36.19 \\
\hline $2004-05$ & 1734.1 & 21.94 \\
\hline $2005-06$ & 1789.9 & 3.21 \\
\hline $2006-07$ & 2472.3 & 38.12 \\
\hline $2007-08$ & 1578.3 & -36.16 \\
\hline $2008-09$ & 2738.4 & 73.50 \\
\hline $2009-10$ & 3307.1 & 20.76 \\
\hline $2010-11$ & 3504.3 & 5.95 \\
\hline $2011-12$ & 3632.0 & 3.64 \\
\hline $2012-13$ & 2692.0 & -25.88 \\
\hline $2013-14$ & 3769.0 & 40.00 \\
\hline $2014-15$ & 3997.0 & 59.11 \\
\hline $2015-16$ & 4454.0 & 25.72 \\
\hline $2016-17$ & 6286.0 & 41.11 \\
\hline
\end{tabular}

Source: Tamil Nadu Electricity Board Statistics at a Glance

Table 3: The Electricity Sales by Public Services in Tamil Nadu

\begin{tabular}{|l|l|l|}
\hline Year & Public Service & Percentage \\
\hline $2000-01$ & 404 & 19.17 \\
\hline $2001-02$ & 408 & 0.99 \\
\hline $2002-03$ & 428 & 5.94 \\
\hline $2003-04$ & 511 & 19.39 \\
\hline $2004-05$ & 528 & 3.33 \\
\hline $2005-06$ & 580 & 9.85 \\
\hline $2006-07$ & 564 & -2.76 \\
\hline $2007-08$ & 518 & -8.16 \\
\hline $2008-09$ & 749 & 44.59 \\
\hline $2009-10$ & 914 & 22.03 \\
\hline $2010-11$ & 914 & 0 \\
\hline $2011-12$ & 1038 & 13.57 \\
\hline $2012-13$ & 1080 & 4.05 \\
\hline $2013-14$ & 1103 & 2.13 \\
\hline $2014-15$ & 1179 & 6.89 \\
\hline $2015-16$ & 1216 & 3.13 \\
\hline $2016-17$ & 1314 & 8.05 \\
\hline
\end{tabular}

Source: Tamil Nadu Electricity Board Statistics at a Glance

\section{Result and Discussion}

In 2000-01, electricity sales by agricultural purposes was 4509.8 million kwh which increased by 1789.9 million kwh in 2005-06. The electricity sales by agricultural purposes trend witnessed increased9030.0million kwh in 2010-11, the electricity sales by agricultural purposes 6296.1 million kwh in 1994-95.

In 2000-01, an electricity sale by commercial purposes was 1172.4millionkwh in which came down to 1578.3 million $\mathrm{kwh}$ in 2007-08. The electricity sales by commercial purposes trend witnessed increase by 11589.8 million kwh in 2010-11.

In 2001-01, electricity sales by public services was 404 million kwh which came down by 518 million kwh in 2007-08. The electricity sales by public services trend witnessed increased 1080 million kwh in 2011-12. The electricity sales to public services 1314 million kwh in 2016- 17.

Table 4: Trend Analysis of Electricity Sales by Agriculture, Commercial and Public Services of Tamil Nadu

\begin{tabular}{|l|l|l|l|l|l|l|}
\hline Sector & Model & A & B & t & $\mathbf{R}^{2}$ & CGR \\
\hline Agriculture & Linear & 869.09 & $\begin{array}{l}355.7 \\
0\end{array}$ & $\begin{array}{l}27.8 \\
0\end{array}$ & 0.96 & - \\
\hline I & Semi-log & 7.61 & 0.065 & $\begin{array}{l}24.7 \\
1\end{array}$ & 0.95 & 6.79 \\
\hline Commercial & Linear & -274.74 & $\begin{array}{l}158.3 \\
3\end{array}$ & $\begin{array}{l}10.6 \\
4\end{array}$ & 0.81 & - \\
\hline II & Semi-log & 6.20 & 0.081 & $\begin{array}{l}22.2 \\
6\end{array}$ & 0.95 & 8.45 \\
\hline Public Services & Linear & -9.61 & 41.53 & $\begin{array}{l}15.7 \\
4\end{array}$ & 0.90 & - \\
& & & & $\begin{array}{l}23.6 \\
4\end{array}$ & 0.95 & 7.88 \\
\hline III & Semi-log & 5.09 & 0.075 & & & \\
\hline
\end{tabular}

\section{Financial Performance}

Table presents some details relating to the financial performance of TNEB for the last year of each plan period starting from the Third Plan. Since the early-seventies, the net surplus for TNEB has been negative, if the subsidy claimed from the government is not taken into account. The gap between the average cost and average revenue per unit sold has been widening. Average revenue per unit fell short of average cost by about 3 paise during the seventies.

The gap increased during the eighties and was as high as 39.41 paise during 2000-01. After registering an improvement during the early-nineties when it fell to about 5.66 paise during 2007-08 it worsened again and during 2010-11 average revenue fell short 
of average cost by about 39 paise. The average cost here is taken to be the total revenue expenses incurred by TNEB per unit of electricity sold rather than the cost per unit at the LT end as is considered in some reports.

During the sixties the return on Net Fixed Assets (NFA) was positive, though it was very low, at 0.62 per cent during 1998-99 and 1.29 per cent during 2001-02. During the seventies the average return on NFA was about -4 per cent and the picture worsened considerably during the eighties. In 2010-11, the return on NFA was as low as -21.33 per cent. There was a significant improvement during the Eighth Plan when the return on NFA was -16.8 per cent. If the subsidy claimed from the state government is taken into account the return on NFA has been positive. It was below 2 per cent till the late-eighties and subsequent to the 1988 amendment of the ESA, requiring a 3 per cent return on NFA, the subsidies claimed have ensured a return of 3 per cent or more.

\section{Suggestions}

1. One watt saved at the point of consumption is more than 1.5 wants generated. It costs about Rs. 4 crore to create new generation capacity. But the same Rs. 4 crore spent on energy conservation methods by and large a one-time expenditure can provide 2-3 MW of available generation capacity and yield results in under two years as against four to five years. In setting up a power plant and transmission and distribution system. Tamil Nadu will have to spike its power generation potential in the years to come energy conservation will undoubtedly help in satiating its growing power need.[7]

2. Non-conventional source of energy being the most environment friendly, there was an urgent need to promote generation of electricity based on such sources of energy; efforts have to been made to reduce the capital cost of projects based on non-conventional and renewable sources of energy. The Electricity Act 2003 provides that co-generation and generation of electricity from non-conventional sources would have to be promoted by state electricity regulatory committees by providing suitable measures for connectivity with grid and sale of electricity to any person.

\section{Conclusion}

Tamil Nadu electricity board ranks second in installed capacity next to Maharastra. The utilization ratio of Tamil Nadu was 5.50 MU in 2005-06. By improving utilization ratio also it is possible to generate additional units of power without incurring additional investments. If Tamil Nadu State Electricity Board continues renovation and modernization programmes the thermal and hydro unit can increase the next generation. Tamil Nadu Electricity Board should fix a realistic tariff that covers the cost of electricity supply and its maintenance. Thus what is needed at this juncture is Tamil Nadu Electricity Board has to make a concerted effort to improve its performance to occupy the first rank.

\section{References}

[1] Central Electricity Authority of India, http://www.cea.nic.in.

[2] Central Electricity Regulatory Commission, http://www.cercind.org

[3] Ministry of Power, Government of India, http://powermin.nic.in.

[4] Oxford Institute for Energy Studies, http://www.oxfordenergy.org.

[5] Published in Gazette of India The Electricity Act, 2003. India: Universal Law Publication Company Pvt. Ltd.
[6] Vindal SS, Saxena NS \& Srivastava SC, "Industry Structure Under Deregulated Wholesale Power Markets in India", Proceedings of International Conference on Present and Future Trends in Transmission and Convergence, (2002).

[7] A Akhmetbekova, P Auyesbayeva, Sh Ibrayev (2018). Turkic "Hikaya" genre and its characters. Opción, Año 33. 81-106. 